\title{
Intravenous ceftriaxone plus clindamycin reduces breast abscess formation in severe lactational mastitis
}

\section{Intraenöz seftriakson ve klindamisin kullanımı şiddetli laktasyonel mastitli hastalarda tedavi sonrası abse gelişimini engellemektedir}

\author{
Fatih Levent Balci ${ }^{1}$, Cihan Uras ${ }^{2}$
}

${ }^{1}$ Department of General Surgery, Medipol Mega University Hospital, Istanbul, Turkey

${ }^{2}$ Department of General Surgery, Acibadem University Research Institute of Senology, Istanbul, Turkey

Corresponding author: Fatih Levent Balci, MD, Department of General Surgery, Medipol Mega University Hospital, Istanbul, Turkey

E-mail: fatihleventbalci@gmail.com

Received/Accepted: June 14, 2019 /September 25, 2019

Conflict of interest: There is not a conflict of interest.

\section{SUMMARY}

Objective: Lactational mastitis can progress to local abscess formation if not treated promptly. The study aims to understand whether the use of intravenous cephalosporin plus clindamycin could reduce breast abscess formation when preferred as a first-line treatment instead of oral penicillin. Method: Patients who admitted to our outpatient clinic with sign and symptoms of lactational mastitis were recruited retrospectively for the study. Patients who had abscess formation on admittance were excluded. Patients were categorized into two groups according to antibiotic preference as the group I with intravenous ceftriaxone plus clindamycin and group II with oral penicillin. Groups were compared according to abscess formation in follow-up by physical examination and ultrasound.

Results: A total of 64 patients with severe lactational mastitis were included. In group I $(n=29)$, only one breast abscess with MSSA was developed. However, seven cases of breast abscess were developed in the second group $(n=35)$. MRSA $(n=4)$, MSSA $(n=1)$, gram-negative bacilli $(n=1)$ and no organism $(n=1)$ were cultured in pus among group II. The prevalence of abscess in group $\mathrm{I}$ is found to be significantly lower in comparison to the control group in 12 weeks follow-up $(\mathrm{p}=0.049)$.

Conclusions: MRSA and gr (-) bacilli are the significant agents in persistent breast abscess formation, which are resistant to oral penicillin or first/second-line cephalosporin. The ceftriaxone plus clindamycin could be used to reduce abscess formation after severe lactational mastitis, therefore, avoids unnecessary operations and hospitalization.

Keywords: Lactational mastitis; puerperal mastitis; breast abscess: nursing woman
Fatih Levent Balc1

Cihan Uras

ORCID IDs of the authors:

F.L.B. 0000-0002-9084-8122

C.U. 0000-0002-6838-2311

\section{ÖZET}

Amaç: Laktasyonel mastit hızla tedavi edilmediğinde lokal meme apsesine dönüşme ihtimali artar. Bu çalışmanın amacı laktasyonel mastit tedavisinde oral penisilin yerine intravenöz sefalosporin ve klindamisin kullanımının tedavi sonrası meme apse oluşumunu engellediğinin araştırılmasıydı. 
kombinasyonu, grup II ise penicilin olarak belirlendi. Gruplar ilk tedavi sonrası fizik muayene ve ultrason yardımı ile apse gelişimi açısından takip edildi.

Bulgular: Șiddetli laktasyonel mastit tanısı konan 64 hasta, Grup I 29 hasta, grup II 35 hasta olarak çalışmaya alındı. Grup I de sadece MSSA nedenli bir apse gelişimi, grup II de ise 7 meme apse gelişimi saptandı. Grup II deki 7 apse gelişen hastada, kültürde 4 hastada MRSA, 1 hastada gram negatif basil saptanırken, bir hastada üreme olmadı. Hastaların 12 haftalık takipleri boyunca Grup I deki apse gelişimi Grup II ye göre istatistiki anlamlı olarak daha düşük prevalanslı bulundu ( $\mathrm{p}=0.049)$.

Sonuç: MRSA ve gr negatif basiller inatçı apse gelişiminde önemli ajanlar olup, oral penisilin veya birinci/ikinci kuşak sefalosporinlere dirençlidir. Intravenöz seftriakson ve klindamisin kombinasyonu, şiddetli laktasyonel mastit hastalarında tedavi sonrası apse gelişimini engelleyerek, apse nedenli ameliyatları ve hastanede kalış süresini azaltır.

Anahtar sözcükler: Laktasyonel mastit, puerperal mastit, meme apsesi

\section{INTRODUCTION}

Lactational mastitis is a common disease in breastfeeding women ${ }^{1,2}$, generally caused by incorrect breastfeeding and poor drainage of breast milk, resulting in accumulation of breast milk and subsequent bacterial infection ${ }^{3}$. Severe lactational mastitis affects the health of mothers and their babies. The clinical manifestations include red, swollen, hot, and tender breast, and the patient may be shivering with high fever, headache, and weakness ${ }^{4}$. Swollen lymph nodes can be observed in the armpit, with an increased inflammatory cell count, which can progress to sepsis in severe cases, affecting the routine feeding of infants ${ }^{5}$.

The formation of abscesses as a complication in patients with severe lactational mastitis is due to inadequate treatment or further aggravation of the disease, tissue necrosis, liquefaction, and infections ${ }^{6}$. The incidence of breast abscess ranges from 0.4 to $11 \%$ of all lactating mothers ${ }^{7}$. The traditional management of breast abscess involves incision and drainage of pus along with anti-staphylococcal antibiotics, but this is associated with prolonged healing time, regular dressings, difficulty in breastfeeding, and the possibility of milk fistula, and unsatisfactory cosmetic outcome. For this reason, some less invasive treatment approaches were tried, such as repeated drainage with a needle instead of surgical incisions ${ }^{8}$.

The conventional treatment approaches for lactational mastitis include: promoting the discharge of milk by massage to solve engorgement or plugged ducts ${ }^{9}$; hot compresses on the breast to help relieve breast swelling and pain ${ }^{10}$, and controlling inflammation by antibiotics ${ }^{11}$. However, for patients with severe lactational mastitis with abscess, in addition to the above treatment approaches, a surgical incision should be performed as early as possible to drain the pus ${ }^{12}$. Therefore, determining the high-risk factors for severe mastitis during the breastfeeding period would be of great clinical significance. Nowadays, MRSA is one of the most cultured agents in the blood or milk of abscess formation causing antibiotic resistance to conventional penicillin treatment. Gram (-) bacilli are also cultured organisms, which are resistant to penicillin and first/second-line cephalosporin ${ }^{13}$. Therefore, the hypothesis was immediate intravenous use of ceftriaxone (third-line cephalosporin) plus clindamycin would be of valid on preventing further local breast abscess formation in comparison to use of conventional oral penicillin. In this study, the clinical data of 64 breastfeeding women who are referred to the outpatient clinic with severe lactational mastitis without breast abscess on admittance were retrospectively analyzed. The study aimed to determine whether the immediate use of IV ceftriaxone plus clindamycin could reduce developing associated breast abscess after severe lactational mastitis in comparison to oral penicillin.

\section{MATERIAL AND METHODS}

\section{Ethics statement}

This study was conducted under the Helsinki Declaration of the World Medical Association. This study only involved a retrospective review of the clinical data, approved by the ethics committee of Istanbul Medipol University (\#10840098604.01.01-E.18409), and all patients signed written informed consent.

\section{Patients}

A total of 181 nursing women, including 105 cases of simple lactational mastitis, 12 severe lactational with breast abscess, and 64 cases of severe lactational mastitis without local breast abscess confirmed by ultrasound and physical examination, admitted to the Department of Breast Surgery in Acibadem Atakent University Hospital from January 2015 to January 2018, were enrolled in the study. In this retrospective analysis of the patient's 
data, standard penicillin or second-line cephalosporins or third-line cephalosporins plus clindamycin were found to be the most selected antibiotic profiles or combinations. Study cases were categorized into two groups according to the preferred antibiotic regimen as the group I with penicillin and group II with third-line cephalosporins plus clindamycin. Patients who had abscess formation on admittance were excluded.

Acute simple lactational mastitis was considered as patients with breast swelling and pain, red skin color, no breast abscess formation, and systemic symptoms such as chills, fever, and headache. Severe lactational mastitis was universally considered as high fever, chills, breast redness and tenderness, breast abscess formation, and inadequate response to conventional conservative treatment.

\section{Study protocol for the treatment of severe lactational mastitis}

All patients initially were treated with conventional conservative therapy, including negative-pressure suction to promote breast milk discharge, hot compress applied to the breast $(30$ min 3 times daily) to promote breast swelling and pain relief. In addition to conservative therapy, in the first group, intravenous ceftriaxone (1000mg) plus clindamycin $(600 \mathrm{mg})$ twice daily for 48 hours was administered to treat severe lactational mastitis. In group II, conventional amoxicillin (875mg) +clavulonate $(125 \mathrm{mg})$ tablets twice daily for one week were used orally for the treatment. Since MRSA and $\operatorname{Gr}(-)$ bacilli have been the reason causing resistance to standard penicillin or cephalosporin treatment in our clinic, we mostly used third-line cephalosporin plus clindamycin affecting those microbial agents. Additionally, for both groups, paracetamol (1000mg) twice daily for one week was used for symptomatic relief. The groups were compared in terms of abscess formation in the following 12 weeks upon admittance. The follow-up procedure was starting with the use of ultrasound and physical examination upon admittance and proceeded with outpatient visits with ultrasound on the first, fourth, and twelve weeks after admittance. No signs, symptoms (e.g., fever, pain, palpitation) or abscess or recurrence of mastitis in 12 weeks follow-up considered as therapeutic success in both groups for severe lactational mastitis. Patients with breast abscess in ultrasound or physical examination on admittance, other infectious diseases, severe heart, kidney, disease, liver, blood disease, or tumors were excluded.

\section{Variables}

Age, primiparous, pluriparous, previous history of antibiotic use during pregnancy, cesarean section or vaginal delivery, nipple excoriation or cracking, previous history of lactational mastitis, postpartum week on admittance, gestational diabetes were the variables affecting the abscess formation in addition to antibiotic treatment among both groups.

\section{Statistical analysis}

Python 3.5 (SK Learn Library) was used for statistical analysis. Kolmogorov Smirnov test was used for normality of scale variables. Fischer's exact test was used to perform the ratio comparison between both groups. Scale Variables averages were compared between two groups with independent sample t-test. Differences were considered statistically significant when p-values were less than 0.05 .

\section{RESULTS}

A total of 64 patients with severe lactational mastitis were included. In group I $(n=29)$, only one breast abscess with MSSA was developed. However, seven cases with breast abscess were recorded in group II $(\mathrm{n}=35)$. MRSA $(\mathrm{n}=4)$, MSSA $(n=1)$, Proteus mirabilis $(n=1)$, no organism $(n=1)$ were cultured in pus among group II. The prevalence of abscess formation in the first group was found to be significantly low in comparison to group II at 12 weeks follow-up $(\mathrm{p}=0.049)$ (Table 1). Distribution of variables was found to be homogeneous, which means the variables did not affect the outcomes of abscess formation between groups (Table 1). According to our study protocol, the therapeutic success rate was $86.2 \%(25 / 29)$ and $74 . .2 \%(26 / 35)$, respectively $(\mathrm{p}=0.104)$. High age, primiparous, and weaning is found to be statistically significant variables that contribute to developing breast abscess $(\mathrm{p}=0.045, \mathrm{p}=0.036$, $\mathrm{p}=0.041$, respectively). Patients in both groups did not have an antibiotic allergy. 
Table 1: Comparison of variables and abscess formation between groups in patients with lactational mastitis

\begin{tabular}{|c|c|c|c|}
\hline & $\begin{array}{l}\text { Group I (IV ceftriaxone } \\
\text { +clindamycin), n, \% }\end{array}$ & $\begin{array}{l}\text { Group II (Oral } \\
\text { penicillin), n, \% }\end{array}$ & $\mathbf{P}=$ \\
\hline Breast abscess formation & $1(3.4 \%)$ & $7(20.8 \%)$ & $\mathbf{0 . 0 4 9}$ \\
\hline Age & $32.1 \pm 9$ & $33.2 \pm 8$ & 0.548 \\
\hline Primiparous & 17 & 20 & 0.554 \\
\hline Pluriparous & 12 & 15 & 0.556 \\
\hline Previous antibiotic use during pregnancy & 7 & 10 & 0.456 \\
\hline Ceserian section & 16 & 19 & 0.572 \\
\hline Normal delivery & 13 & 16 & 0.572 \\
\hline Nipple cracking or fissure & 8 & 10 & 0.557 \\
\hline Previous history of lactational mastitis & 5 & 5 & 0.505 \\
\hline Mastitis recurrence in 12 weeks follow-up & 3 & 2 & 0.410 \\
\hline MSSA in pus culture & 1 & 1 & 0.505 \\
\hline MRSA in pus culture & 0 & 4 & 0.112 \\
\hline Gr (-) bacillus in pus culture & 0 & 1 & 0.571 \\
\hline No organism in pus culture & 0 & 1 & 0.571 \\
\hline Gestational diabetes & 4 & 7 & 0.377 \\
\hline Weaning & 2 & 3 & 0.590 \\
\hline Engorgement & 2 & 3 & 0.590 \\
\hline ***Weeks postpartum on admittance for mastitis & $10.52 \pm 6.51$ & $11.54 \pm 6.99$ & 0.549 \\
\hline Therapeutic success rate & $25(86.2 \%)$ & $26(74.2 \%)$ & 0.104 \\
\hline
\end{tabular}

Fischer's exact test $\quad$ ***Independent Sample t-test

\section{DISCUSSION}

Acute bacterial mastitis either resolves under antibiotic therapy or evolves toward a pyogenic abscess. The gold standard for the treatment of breast abscesses is surgical incision, drainage, and administration of systemic antibiotics ${ }^{14,15}$. To increase the therapeutic success of acute bacterial mastitis or associated abscess, minimally invasive drainage techniques with adjunctive antimicrobial drug therapy has been used. More data about the type of pathogens responsible for breast abscesses and their resistance patterns could help the surgeon to choose the correct empirical treatment. The bacteriology of breast abscesses has been studied in the past, identifying Staphylococcus aureus as the predominant bacterial isolate ${ }^{16,}{ }^{17}$. As outpatient infection with methicillin-resistant $\mathrm{S}$. aureus (MRSA) becomes increasingly common, physicians need to be aware of the local prevalence and sensitivities of this organism. Organisms other than S. aureus have rarely been implicated as the cause of mastitis. These include fungi such as Candida albicans, as well as group A betahemolytic Streptococcus, Streptococcus pneumoniae, Escherichia coli, and Mycobacterium tuberculosis ${ }^{18}$.

The diagnosis of mastitis is generally made clinically. Patients typically present with localized, unilateral breast tenderness, and erythema, accompanied by a fever of $38.5^{\circ} \mathrm{C}$, malaise, fatigue, body aches, headache, and swollen lymph nodes ${ }^{19}$. Culture is rarely used to confirm bacterial infection of the milk because positive cultures can result from healthy bacterial colonization, and negative cultures do not rule out mastitis ${ }^{20}$. Culture of blood or milk has been recommended when the infection is severe, unusual, or hospital-acquired, or if it fails to respond to two days of treatment with appropriate antibiotics ${ }^{21}$. Culture can also be considered in localities with a high prevalence of bacterial resistance. Since cases of the study selected among patients with severe lactational mastitis, most cases with abscess formation had pus culture but rarely blood culture. MRSA was the leading agent collected from the patients with abscess formation followed by MSSA and gramnegative bacilli.

Because the mother and infant are usually colonized with the same organisms at the time mastitis develops, breastfeeding can continue during an episode of mastitis without the worry of the bacterial infection being transmitted to the infant ${ }^{21}$. Continuation of breastfeeding does not pose a risk to the infant; in fact, it allows for a higher chance of breastfeeding after the resolution of the mastitis and allows for the most efficient removal of the breast milk from the affected area. In the study, patients do not stop breastfeeding on the ipsilateral side, even if the patient had mastitis or abscess on the affected side.

In addition to draining breast milk as thoroughly as possible, antibiotics are often necessary to treat mastitis. Few studies are available to guide the physician in determining when antibiotics are needed, or in selecting antibiotics. If a culture was obtained, results could guide therapy. Because the most common infecting organism is S. aureus, antibiotics that are effective against this organism 
should be selected empirically ${ }^{18}$. Besides, there are many gram-negative bacilli of medical significance. The most important of these are members of the family Enterobacteriaceae. Serratia, Proteus, Citrobacter, and Enterobacter are all members of the family Enterobacteriaceae that, collectively, are sometimes referred to as "SPICE" enteric Gram-negative bacilli ${ }^{22}$. These genera are organisms of particular concern in hospitals and are inherently resistant to antibiotics. The types of enteric gram-negative bacilli that are found in particular institutions influence the selection of antibiotics for hospital-acquired infections. In the current study, only one gram-negative bacillus is found in the culture of abscess collected from the control group. Even though the rate is low, this finding may contribute to the hypothesis of prompt administration of intravenous cephalosporin to prevent associated abscess in the course of severe mastitis.

One of the most common complications of mastitis is the cessation of breastfeeding. Mothers should be reminded of the many benefits of breastfeeding and encouraged to continue. Another potential complication is the development of an abscess, which presents similarly to mastitis except that there is a secure area in the breast, often with fluctuation. An abscess can be confirmed by ultrasonography and should be treated with surgical drainage or needle aspiration, which may need to be repeated. Fluid from the abscess should be cultured, and antibiotics should be administered. Breastfeeding usually can continue, except if the mother is severely ill or the infant's mouth must occlude the open incision when feeding ${ }^{23}$. Because inflammatory breast cancer can resemble mastitis, this condition should be considered when the presentation is atypical or when the response to treatment is not as expected. In the study, no inflammatory breast cancer recorded among patients who admitted to the outpatient clinic with mastitis. Except in two patients, the abscess formation did not cause weaning.

In conclusion, the data presented in this study indicate that antibiotics chosen for the treatment of severe lactational mastitis with breast abscess should be effective against MRSA as well as gramnegative bacilli. Intravenous ceftriaxone plus clindamycin could prevent breast abscess formation after severe lactational mastitis if administered promptly. Oral penicillin could be preferred in selected patients with acute mastitis, who do not have an abscess or clinical signs indicating sepsis. Future studies are needed to determine whether the immediate use of IV combination of antibiotics could be cost-effective by reducing drainage interventions and associated hospitalization.

\section{REFERENCES}

1. Kinlay JR, O'Connell DL, Kinlay S. Incidence of mastitis in breastfeeding women during the six months after delivery: A prospective cohort study. Med J Aust. 1998;169(6):310-12.

2. Vogel A, Hutchison BL, Mitchell EA. Mastitis in the first year postpartum. Birth. 1999;26(4):21825.

3. Fetherston C. Mastitis in lactating women: physiology or pathology? Breastfeed Rev. 2001;9(1):5-12.

4. Amir LH. ABM clinical protocol \#4: Mastitis, revised in March 2014. Breastfeed Med. 2014;9(5):239-43.

5. Bolman M, Saju L, Oganesyan K, et al. Recapturing the art of therapeutic breast massage during breastfeeding. J Hum Lact. 2013;29(3):328-31.

6. Thomsen AC, Espersen T, Maigaard S. Course and treatment of milk stasis, noninfectious inflammation of the breast, and infectious mastitis in nursing women. Am $\mathrm{J}$ Obstet Gynecol. 1984;149(5):492-95.

7. Dener C, Inan A. Breast abscesses in lactating women. World J Surg. 2003;27(2):130-133.

8. Berens PD. Prenatal, intrapartum, and postpartum support of the lactating mother. Pediatr Clin North Am. 2001;48(2):365-375.

9. Witt AM, Bolman M, Kredit S, Vanic A. Therapeutic breast massage in lactation for the management of engorgement, plugged ducts, and mastitis. J Hum Lact. 2016;32(1):123-31.

10. Ioffe IV, Chernova NV. [Efficacy of surgical treatment of patients for acute lactational mastitis using a radiofrequency scalpel and ozoneultrasonic method].KlinKhir. 2013;(1):65-68. [in Russian]

11. Feijen-de Jong EI, Baarveld F, Jansen DE, et al. Do pregnant women contact their general practitioner? A register-based comparison of healthcare utilization of pregnant and non-pregnant women in general practice. BMC FamPract. 2013;14:10.

12. Amir LH, Trupin S, Kvist LJ. Diagnosis and treatment of mastitis in breastfeeding women.J Hum Lact. 2014;30(1):10-13.

13. Reddy PN, Srirama K, Dirisala VR. An Update on Clinical Burden, Diagnostic Tools, and 
Therapeutic Options of Staphylococcus aureus. Infect Dis (Auckl). 2017;10:1179916117703999.

14. Meguid MM, Oler A, Numann PJ, Khan S: Pathogenesis-based treatment of recurring subareolar breast abscesses. Surgery 1955; 118:775-782.

15.Dixon JM: Outpatient treatment of nonlactational breast abscesses. Br J Surg 1992;79: 5657.

16. Walker AP, Edmiston CE Jr, Krepel CJ, Condon RE: A prospective study of the microflora of non-puerperal breast abscess. Arch Surg 1988;123:908-911.

17. Brook L: Microbiology of non-puerperal breast abscesses. J Infect Dis 1988;157:377-379.

18. Lawrence RA, Lawrence RM. Management of the mother-infant nursing couple. In: Breastfeeding: A Guide for the Medical Profession. 6th ed. St. Louis, Mo.: Mosby; 2005:255-316.
19. Wambach KA. Lactation mastitis: a descriptive study of the experience. J Hum Lact. 2003;19(1):24-34.

20. Osterman KL, Rahm VA. Lactation mastitis: bacterial cultivation of breast milk, symptoms, treatment, and outcome. J Hum Lact. 2000;16(4):297-302.

21. Department of Child and Adolescent Health and Development. Mastitis: causes and management. Geneva, Switzerland: World Health Organization; 2000. http://whqlibdoc.who.int/hq/2000/WHO_FCH_C AH_00.13.pdf. Accessed June 15, 2008.

22. Moazzez A, Rebecca L, Kelso RL, et al. Breast abscess bacteriologic features in the era of community-acquired methicillin-resistant Staphylococcus aureus epidemics. Arch Surg 2007;142:881-884.

23. Prachniak GK. Common breastfeeding problems.Obstet Gynecol Clin North Am. 2002;29(1):77-88. 